\title{
Virulence of Aphanomyces euteiches Isolates from Iowa and Wisconsin and Benefits of Resistance to A. euteiches in Alfalfa Cultivars
}

\author{
G. P. Munkvold, Department of Plant Pathology, Iowa State University, Ames 50011; W. M. Carlton, Iowa State \\ University Cooperative Extension, 107 E. Benton, Albia 52531; E. C. Brummer, Department of Agronomy, Iowa \\ State University, Ames 50011; J. R. Meyer, 701 Ridge St., Madison, WI 53705; D. J. Undersander, Department of \\ Agronomy, University of Wisconsin, and C. R. Grau, Department of Plant Pathology, University of Wisconsin, \\ Madison 53706
}

\begin{abstract}
Munkvold, G. P., Carlton, W. M., Brummer, E. C., Meyer, J. R., Undersander, D. J., and Grau, C. R. 2001. Virulence of Aphanomyces euteiches isolates from Iowa and Wisconsin and benefits of resistance to A. euteiches in alfalfa cultivars. Plant Dis. 85:328-333.

Aphanomyces euteiches has become recognized as an important root rot pathogen of alfalfa in the north-central United States, and resistant cultivars are now commonly planted. Recent evidence indicates the existence of $A$. euteiches strains, designated as race 2, that are virulent on resistant cultivars, but there is little information on the prevalence of such strains or their impact on the performance of A. euteiches-resistant cultivars. The purpose of this study was to assess the virulence of $A$. euteiches isolates obtained from Iowa and Wisconsin soils and to determine the frequency of isolates virulent on race 1-resistant alfalfa populations. In addition, the yield performance of susceptible and resistant alfalfa populations was compared in four Iowa locations and one Wisconsin location. Fourteen isolates of A. euteiches from different Iowa locations were used to challenge two race 1-resistant cultivars (Paramount and Quantum), a susceptible cultivar (Agate or Vernal), and two resistant breeding populations (WAPH-1 and WAPH2). Fifty-nine isolates of A. euteiches from one location in Wisconsin were used to challenge one susceptible cultivar (Saranac) and WAPH-1 and WAPH-2. Every isolate was virulent to one or more alfalfa cultivars or populations. Emergence of seedlings in growth chamber experiments did not differ significantly among isolates or alfalfa populations. Alfalfa population and A. euteiches isolate had significant effects on disease severity index (DSI, 1-5 scale), but there were significant interactions $(P<0.05)$ between these two effects. All 14 Iowa isolates of $\mathrm{A}$. euteiches were virulent (DSI $\geq 3.0$ ) on Agate (mean DSI $=4.4$, range 3.8 to 4.9), WAPH-1 (mean DSI $=3.9$, range 3.0 to 4.4 ), and the two commercial resistant cultivars (mean DSI $=3.9$ and 4.1, range 3.2 to 4.4). On WAPH-2, only three isolates were virulent (mean DSI $=2.5$, range 1.8 to 3.2). Of 59 Wisconsin isolates, all were virulent on Saranac (mean DSI $=4.6$, range 3.9 to 5.0 ), 21 were virulent on WAPH-1 (mean DSI $=2.9$, range 1.8 to 4.8 ), and only four were virulent on WAPH-2 (mean DSI $=2.3$, range 1.8 to 3.4 ). In field studies, we compared yield performance of alfalfa cultivars that were resistant or susceptible to A. euteiches or Phytophthora medicaginis at four Iowa locations for one to three harvest years, and one Wisconsin location for two harvest years. Mean yields of cultivars with resistance to one or both pathogens were significantly higher than those of susceptible cultivars in only one of the four Iowa locations. In Wisconsin, WAPH-4, a Race 2-resistant alfalfa population, expressed a significant yield advantage when compared with both WAPH-1, a Race 1-resistant alfalfa population, and Columbia 2000, a cultivar susceptible to both race 1 and 2 of A. euteiches. These results indicate that race 2 of $A$. euteiches is prevalent in Iowa and Wisconsin soils and may be limiting the yield benefits of currently available race 1 -resistant alfalfa cultivars. Incorporation of race 2 resistance is likely to improve the performance of alfalfa cultivars in A. euteiches-infested soils.
\end{abstract}

Additional keywords: Medicago sativa

Aphanomyces euteiches Drechs. is a widely distributed soil oomycete that is a root pathogen of alfalfa, beans, clover, pea,

Corresponding author: G. P. Munkvold

E-mail: munkvold@iastate.edu

Journal paper J-18931 of the Iowa Agriculture and Home Economics Experiment Station, Ames, Project 3260, supported by Hatch Act and State of Iowa funds.

Accepted for publication 4 December 2000.

Publication no. D-2001-0116-02R

(C) 2001 The American Phytopathological Society the northeastern counties where most of the alfalfa in the state is grown (24). A. euteiches was widespread and possibly more prevalent than $P$. medicaginis in Iowa alfalfa fields. Similar results have been found in Kentucky (29) and Wisconsin (3).

Incorporating resistance to $P$. medicaginis into alfalfa breeding lines has been an effective way to reduce losses due to this pathogen $(4,10,19)$. Germ plasm resistant to root rot caused by A. euteiches has also been identified, and alfalfa populations have been improved for $A$. euteiches resistance $(6,7,13,31)$. Many new cultivars released today have high levels of resistance to Phytophthora root rot (PRR) and frequently have moderate to high levels of A. euteiches resistance (2).

Several investigators have reported isolates of A. euteiches to express physiologic specialization for differential pea lines $(1,20-22)$ and alfalfa populations $(8,9,14)$. Virulence for specific alfalfa population- $A$. euteiches isolate interactions has been defined based on a 1 to 5 disease severity scale, with disease severity scores $\geq 3.0$ designated as a virulent reaction (9). Although differential virulence to host forms is known to occur within populations of $A$. euteiches, it is not known if the more virulent isolates represent a barrier to development of resistant cultivars in pea or a risk to the known resistance within commercial alfalfa cultivars. Some isolates of A. euteiches have a limited host range, and those pathogenic to alfalfa can differ in their virulence to specific alfalfa cultivars $(8,9,13)$. Strains of $A$. euteiches have been found that are virulent to both Saranac (a susceptible cultivar) and WAPH-1 (the standard resistant breeding population) (9). Subsequently, A. euteiches strains that are avirulent or have low virulence to WAPH1 have been designated as race 1 , and those that are highly virulent to WAPH-1 have been designated as race 2. A system has been proposed for identification of $\mathrm{A}$. $\mathrm{eu}$ teiches races 1 and 2 based on the reactions of WAPH-1, WAPH-5 (a newly released resistant population), and a susceptible cultivar (usually Agate or Saranac) (15).

To protect and enhance the use of host resistance in reducing losses caused by Aphanomyces root rot, it is important to determine whether strains of the pathogen are present that are capable of overcoming 
the genetic resistance of alfalfa cultivars. The purpose of this study was to determine the variability in virulence among strains of A. euteiches in Iowa and Wisconsin and to determine if currently available resistant cultivars provide a yield advantage over susceptible cultivars in Iowa and Wisconsin alfalfa fields where A. euteiches is present.

\section{MATERIALS AND METHODS}

Collection of Iowa and Wisconsin isolates. Soil and plant samples collected in a survey of Iowa alfalfa fields (24) were assayed for the presence of $A$. euteiches by the seedling baiting method (30) using the susceptible alfalfa cultivar Vernal. Bait seedlings were examined microscopically for presence of $A$. euteiches oospores and sporangia. Seedlings infected during the assay were placed on MBV agar (corn meal agar with $30 \mathrm{ppm}$ metalaxyl, $5 \mathrm{ppm}$ benomyl, and 200 ppm vancomycin) (26) for isolation of the fungus. Cultures were identified as A. euteiches by mycelial, sporangial, and oogonial characteristics (16). Twenty arbitrarily selected A. euteiches isolates from soil were transferred to fresh MBV agar and maintained at $22^{\circ} \mathrm{C}$. Six isolates did not produce zoospores and were not included in the study; the remaining 14 isolates came from 11 different Iowa counties (Table 1). Cropping history of the source fields is not known.

In Wisconsin, a field located at the Lancaster Agricultural Research Station in southwest Wisconsin was sampled for isolates of A. euteiches. Alfalfa cultivars resistant to $A$. euteiches race 1 have a history of poor agronomic performance at this location. Soil was assayed for Aphanomyces using a baiting procedure patterned after Schmitthenner (27) and Grau et al. (9). Seed (cv. Saranac) was treated with metalaxyl $(0.1 \mathrm{~g}$ a.i. per $100 \mathrm{~g}$ of seed, formulated as Apron 25W) to suppress infection by $P$. medicaginis and Pythium spp. Thereafter, further steps were identical to those used to assay the Iowa soils.
Characterization of Iowa and Wisconsin isolates. The virulence of Iowa and Wisconsin A. euteiches isolates was tested in separate experiments. Zoospores were used to inoculate seedlings planted in sterile potting media in plastic or paper cups. Zoospores were obtained by the procedure described by Parke and Grau (25); disks from CMA cultures were incubated in peptone glucose broth and rinsed with sterile lake-water. Once zoospores were released, their concentration in suspension was adjusted so that 2,000 spores were added to each cup in 1 to $2 \mathrm{ml}$ of lakewater suspension.

For the 14 Iowa isolates, five different alfalfa populations or cultivars were planted in sterile vermiculite with 20 seeds in each 100-ml paper cup. One cup of each population or cultivar was inoculated with each of the A. euteiches isolates. Cups were arranged in a completely randomized design in a growth chamber. The experiment was performed three times, and each repetition of the experiment was treated as a replicate block for the purpose of analyses. The cultivars Agate or Vernal were used as the susceptible checks. The other entries were WAPH-1 and WAPH-2, two alfalfa populations selected for resistance to A euteiches and used for breeding purposes $(6,7)$, and Paramount and Quantum, two commercial cultivars rated as resistant to A. euteiches and which employ mainly the WAPH-1 or a similar source of resistance. The seedlings were kept at $24^{\circ} \mathrm{C}$ with 12-h light per day and were watered daily. Six days after planting, the cups were flooded with deionized water and inoculated with $A$. euteiches zoospores. One week after inoculation, plants were fertilized with Hoagland's solution (11).

Fifty-nine Wisconsin isolates of $\mathrm{A}$. euteiches were characterized for virulence phenotype on three alfalfa populations: Saranac, WAPH-1, and WAPH-2. Saranac, a susceptible population, discriminated between pathogenic and nonpathogenic isolates. Ten seeds of each alfalfa population were planted in 500-ml solid-bottomed plastic containers (Conex, Dart Container Co., Mason, MI) filled with approximately $300 \mathrm{ml}$ of coarse vermiculite. All three alfalfa populations were planted in each container using an arrangement that was analogous to hill plots. Each isolate and alfalfa population combination was replicated three times. The seeds were covered with approximately $3 \mathrm{~mm}$ of coarse vermiculite, then flooded with deionized water to saturate the system. The containers were placed in a growth chamber at $24^{\circ} \mathrm{C}$. Six days after planting, seedlings were inoculated as described above and incubated at $24^{\circ} \mathrm{C}$ at a $16-\mathrm{h}$ photoperiod for 14 days.

In each experiment, 2 weeks after inoculation, the number of seedlings emerged in each cup was counted and recorded as a percentage of seedlings emerged in the control cup. Emerged seedlings were counted even if they were dead at the time of assessment. Seedlings were removed from the cups and rated for symptoms of infection by A. euteiches using the following scale (Disease Severity Index, DSI) (9): 1 = no to very slight discoloration of roots and hypocotyl; $2=$ slight necrosis of roots and hypocotyl; $3=$ necrosis of roots and hypocotyl, slight chlorosis of cotyledons, and moderate stunting of stems; $4=$ extensive necrosis of roots, hypocotyl, and cotyledons, and severe stunting of stems; and $5=$ dead. When emergence was lower in inoculated cups than in the control, seedlings that failed to emerge were counted as a 5. For each block, scores were recorded as the mean rating for each cup. Isolates were considered virulent if the mean score was $\geq 3.0$ (9). One symptomatic seedling from each cup was surface-disinfested with $0.5 \%$ $\mathrm{NaOCl}$ for 1 min and placed on MBV agar for re-isolation of $A$. euteiches.

Emergence and disease ratings were analyzed by ANOVA (SAS Version 6.12,

Table 1. Emergence (\%) of alfalfa populations or cultivars inoculated in the growth chamber with Iowa isolates of Aphanomyces euteiches ${ }^{\mathrm{a}}$

\begin{tabular}{|c|c|c|c|c|c|c|c|}
\hline \multirow[b]{2}{*}{ Isolate } & \multirow[b]{2}{*}{ Origin } & \multicolumn{5}{|c|}{ Alfalfa population or cultivar } & \multirow{2}{*}{$\begin{array}{c}\text { Mean } \\
(\%)\end{array}$} \\
\hline & & Agate & Quantum & Paramount & WAPH-1 & WAPH-2 & \\
\hline 111 & Montgomery Co., IA & 92 & 92 & 60 & 100 & 75 & 84 \\
\hline 71 & Ringgold Co., IA & 88 & 75 & 86 & 74 & 84 & 81 \\
\hline 86 & Clarke Co., IA & 90 & 75 & 81 & 89 & 88 & 85 \\
\hline 112 & Montgomery Co., IA & 82 & 89 & 83 & 89 & 89 & 86 \\
\hline 75 & Allamakee Co., IA & 97 & 82 & 89 & 85 & 92 & 89 \\
\hline 100 & Linn Co., IA & 83 & 83 & 81 & 90 & 96 & 87 \\
\hline 98 & Cedar Co., IA & 95 & 80 & 88 & 76 & 96 & 87 \\
\hline 90 & Iowa Co., IA & 77 & 90 & 92 & 90 & 98 & 89 \\
\hline 89 & Benton Co., IA & 87 & 87 & 77 & 92 & 98 & 88 \\
\hline 116 & Dubuque Co., IA & 95 & 85 & 91 & 99 & 98 & 94 \\
\hline 62 & Monroe Co., IA & 100 & 80 & 84 & 84 & 98 & 89 \\
\hline 109 & Pottawattamie Co., IA & 60 & 89 & 94 & 73 & 100 & 83 \\
\hline 73 & Ringgold Co., IA & 88 & 85 & 90 & 99 & 100 & 92 \\
\hline \multirow[t]{3}{*}{72} & Ringgold Co., IA & 93 & 89 & 83 & 89 & 100 & 91 \\
\hline & Uninoculated & 100 & 100 & 100 & 100 & 100 & 100 \\
\hline & Mean & 88 & 85 & 85 & 89 & 94 & 88 \\
\hline
\end{tabular}

${ }^{a}$ Data are means of three experiments. Emergence did not differ significantly $(P>0.05)$ among isolates or alfalfa populations. 
SAS Institute, Cary, NC) with each repetition of the experiment treated as a replicate block.

Field studies. The performance of alfalfa cultivars resistant or susceptible to $A$. euteiches was evaluated on plots established for the annual alfalfa crop performance tests in Iowa (2). The plots contained five rows, $3.66 \mathrm{~m}$ long and spaced $10 \mathrm{~cm}$ apart. The experimental design was a randomized complete block with four replicate blocks at each location. Plots were located in: Ames (Iowa State University Agronomy Farm, Boone Co., central Iowa); Castana (Iowa State University Western Research Farm, Monona Co., west-central Iowa); McNay (Iowa State University McNay Research Farm, Lucas Co., south-central Iowa); and Nashua (Iowa State University Northeast Research Farm, Floyd Co.) (Table 2). Soil types differ significantly among the locations: the Ames location has a tile-drained, Nicollet loam (fine-loamy, mixed, superactive, mesic Aquic Hapludolls); the soil at Castana is a Monona silt loam (fine-silty, mixed, superactive, mesic Typic Hapludolls); at the McNay location the soil is a Grundy silty clay loam (fine, smectitic, mesic Aquertic Argiudolls); and at Nashua the test site has a Readlyn loam (fineloamy, mixed, mesic Aquic Hapludolls).

The Iowa plots were planted between 1991 and 1996 at a seeding rate of 20 $\mathrm{kg} / \mathrm{ha}$ and fertilized annually according to soil test recommendations. After the first harvest, $225 \mathrm{~kg}$ of $\mathrm{K}_{2} \mathrm{O}$ per hectare was applied. Established tests were harvested three or four times per year at the late bud to mid-bloom stage. New tests were harvested three times per year. This study included 1 to 3 years of yield data from each of 12 alfalfa stands (26 individual data sets) ranging in age from seeding-year to 3 years old. Yield was expressed as metric tons of dry matter per hectare. During the 1994 survey, soil samples from field locations were evaluated for $\mathrm{A}$. $\mathrm{eu}$ teiches and $P$. medicaginis. Both fungi were detected in samples from the McNay location, and A. euteiches was detected in samples from the Ames and Nashua locations.
For analysis, cultivars in each test location were grouped into resistant/highly resistant or susceptible to $A$. euteiches and $P$. medicaginis based on descriptions published by the Certified Alfalfa Seed Council and from the Association of Official Seed Certifying Agencies. Resistance ratings are based on the percentage of plants in a given cultivar that are resistant to $A$. euteiches. Susceptible cultivars include 0 to $5 \%$ resistant plants; cultivars with low resistance contain 6 to $4 \%$ resistant plants; moderately resistant cultivars have 15 to $30 \%$ resistant plants; resistant cultivars have 31 to $50 \%$ resistant plants; and highly resistant cultivars include $>50 \%$ resistant plants (2). Ratings for A. euteiches were based on resistance to race 1 of $A$. euteiches. Cultivars rated as having low or moderate resistance to either pathogen were not included in the analysis. The following overlapping groups were used for analysis: (i) A. euteiches-resistant cultivars (regardless of $P$. medicaginis resistance), (ii) A. euteiches-susceptible cultivars (regardless of $P$. medicaginis resistance), (iii) $P$. medicaginis-resistant cultivars (regardless of $A$. euteiches resistance, (iv) $P$. medicaginis-susceptible cultivars (regardless of A. euteiches resistance), (v) cultivars resistant to both pathogens, and (vi) cultivars susceptible to both pathogens. Because groups 1, 2, 3, and 4 were formed based only on resistance to one or the other pathogen, cultivars were included in more than one group. Preliminary analysis of individual locationyears showed that there were no significant interactions between year of planting or year of harvest and cultivar resistance, so data from all planting dates and harvest dates were combined within locations. For the analysis, the mean yields of all cultivars in each group for each field plot were treated as the experimental observations. Analysis of covariance (18) was used to assess differences in yields among cultivar groups within each location, with harvest year as the covariable. Mean separation was conducted by the LSMEANS option of the General Linear Models procedure of SAS (Version 6.12, SAS Institute, Cary, NC).
One field study was conducted in Wisconsin at the Lancaster Agricultural Research Station in the same field plot location from which the 59 A. euteiches isolates were recovered. The soil type at this location is a Rozetta silt loam and is classified as a Typic Hapludalf, fine-silty mixed mesic. The field site is naturally infested with alfalfa-infecting strains of $A$. euteiches and $P$. medicaginis. Alfalfa populations in the Wisconsin field study were selected on the basis of reaction to races of A. euteiches. Columbia 2000 has low resistance to races 1 and 2 of $A$. euteiches and $P$. medicaginis, WAPH-1 has resistance to race 1 of $A$. euteiches and high resistance to $P$. medicaginis (6), and WAPH-4 has high resistance to race 1 and resistance to race 2 of $A$. euteiches, and moderate resistance to $P$. medicaginis. The plots were planted May 1998 at a seeding rate of $10 \mathrm{~kg} / \mathrm{ha}$ with a Wintersteiger TC 2700 Planter (Wintersteiger Seedmech, Salt Lake City, UT) and were $1.2 \mathrm{~m}$ wide, seven rows spaced $15 \mathrm{~cm}$ apart, and $7.6 \mathrm{~m}$ long. Experimental design was a randomized complete block with four replicate blocks. The plot was harvested once in the establishment year and twice the second year. All harvests were made at the early bud to early-bloom stage. Plots were harvested with an Almaco Forage Harvester Model FH (Allen Machine Company, Nevada, IA). Plots were fertilized annually according to soil test recommendations.

\section{RESULTS AND DISCUSSION}

Growth chamber studies. Mean percent emergence of seedlings inoculated with Iowa isolates ranged from $81 \%$ (isolate 71) to $94 \%$ (isolate 116) among $A$. euteiches isolates and from $85 \%$ (cv. Quantum) to $94 \%$ (WAPH-2) among alfalfa populations. There were no significant effects of isolate $(P=0.175)$ or alfalfa population $(P=0.056)$ in terms of emergence, nor was their interaction significant $(P=0.838)$. In specific combinations of isolate and alfalfa population, emergence of the most susceptible cultivar, Agate, inoculated with $A$. euteiches, ranged from 60 to $100 \%$, and emergence of the most resistant alfalfa line, WAPH-2, ranged

Table 2. Location, soil type, number of years harvested, and number of alfalfa cultivars planted at each Iowa test site susceptible and resistant to Aphanomyces euteiches

\begin{tabular}{|c|c|c|c|c|c|c|}
\hline Location & Soil type & $\begin{array}{c}\text { Pathogens } \\
\text { detected }^{\mathbf{a}}\end{array}$ & Stand established & Years harvested & $\begin{array}{l}\text { Susceptible } \\
\text { cultivars }\end{array}$ & $\begin{array}{l}\text { Resistant } \\
\text { cultivars }\end{array}$ \\
\hline Ames & Tile-drained Nicollet loam & $\mathrm{Ae}$ & 1993 & 1993-1996 & 14 & 20 \\
\hline Ames & & & 1994 & 1994-1997 & 6 & 12 \\
\hline Ames & & & 1995 & 1995-1997 & 7 & 19 \\
\hline Ames & & & 1996 & 1997 & 3 & 13 \\
\hline Castana & Monona silt loam & $\ldots$ & 1994 & 1994-1997 & 3 & 11 \\
\hline Castana & & & 1996 & 1997 & 4 & 13 \\
\hline McNay & Grundy silty clay loam & $\mathrm{Ae}+\mathrm{Pm}$ & 1991 & 1992 & 12 & 2 \\
\hline McNay & & & 1993 & 1994-1996 & 12 & 13 \\
\hline McNay & & & 1996 & 1997 & 3 & 9 \\
\hline Nashua & Readlyn loam & $\mathrm{Ae}$ & 1994 & 1995-1996 & 5 & 15 \\
\hline Nashua & & & 1995 & 1996 & 3 & 14 \\
\hline Nashua & & & 1996 & 1997 & 5 & 22 \\
\hline
\end{tabular}


from 75 to $100 \%$ (Table 1). These results reflect the relatively minor effect that $A$. euteiches can have on emergence compared with $P$. medicaginis. Symptoms of $A$. euteiches infection of seedlings are usually manifested as stunting or postemergence death (5).

The disease severity index was a better indication of virulence than emergence, because many seedlings emerged but later died due to infection. Every isolate of $A$. euteiches used in the study was virulent on one or more alfalfa populations, and isolates demonstrated distinct variability in virulence. Alfalfa population and $A$. euteiches isolate had significant effects on disease severity $(P<0.0001)$, but the interaction also was significant $(P=0.001)$. All 14 Iowa isolates of $A$. euteiches were virulent $(\mathrm{DSI} \geq 3.0)$ on Agate (mean DSI = 4.4 , range 3.8 to 4.9 ), WAPH-1 (mean DSI $=3.9$, range 3.0 to 4.4 ), and the two commercial resistant cultivars (mean DSI $=3.9$ and 4.1 , range 3.2 to 4.4 ). On WAPH-2, only three isolates were virulent (mean DSI $=2.5$, range 1.8 to 3.2) (Table 3). Considering all the alfalfa populations, five isolates caused a mean DSI $\geq 4.0$ on all lines except WAPH2. Two isolates caused a mean DSI $\geq 3$.0 but $<4.0$ on all but WAPH-2. Seven isolates caused a mean DSI $\geq 4.0$ on Agate but lower on one or more of the resistant lines. Only WAPH-2 was resistant to most isolates, and it had the lowest mean disease severity for each isolate.

The results of the growth chamber studies on Iowa isolates were similar to those of Grau et al. $(8,9)$, but among the Iowa isolates there was a higher proportion of isolates $(100 \%)$ virulent on WAPH- 1 . The A. euteiches isolates used in this study differed in severity of disease symptoms they caused, but all would be considered virulent (disease severity index $\geq 3.0$ ) on the commercial resistant cultivars and WAPH-1. The Iowa isolates were not tested against the resistant standard for race 2 (WAPH-5), but virulence on WAPH-1 and avirulence on WAPH-2 would be consistent with race 2 strains (15). Only a small number of Iowa isolates were tested; they represented an arbitrary sample of isolates from across the state. This sample is not suitable for a quantitative estimate of race 2 prevalence in the state, but the fact that all 14 isolates were virulent on race 1-resistant cultivars suggests that race 2 is common in Iowa. Race 2 resistance is available in only a few commercial cultivars. Breeding resistance to race 2 into more commercial cultivars could provide a valuable tool for forage producers in the state.

All Wisconsin isolates were virulent on Saranac (mean DSI $=4.6$, range 3.9 to
5.0). In contrast to the Iowa isolates, only $36 \%$ of the Wisconsin isolates caused DSI $>3.0$ on WAPH-1. Four of the 59 isolates were rated as highly virulent (DSI > 4.0) on WAPH-1 (Fig. 1). Most Wisconsin isolates (55 of 59 total isolates) from this site were not virulent to WAPH-2 (mean DSI $=2.3$, range 1.8 to 3.4 ). Thus, the Wisconsin site was chosen to evaluate the performance of alfalfa germ plasm selected for resistance to race 2 .

Field studies. Yields of cultivars with resistance to $A$. euteiches and $P$. medicaginis were numerically higher at three of the four Iowa locations (Ames, McNay, and Nashua), but there was a statistically significant difference only at the McNay location (Fig. 2), where the cultivar group with resistance to $A$. euteiches

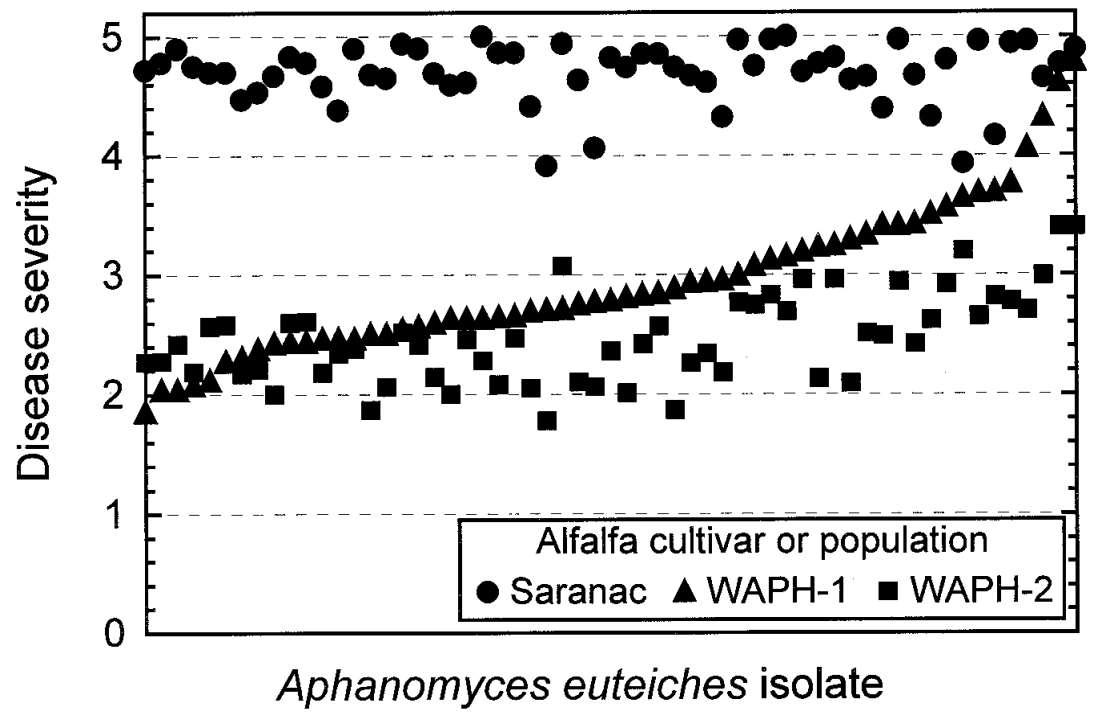

Fig. 1. Disease severity index for three alfalfa populations inoculated with Aphanomyces euteiches isolates from the same field in Lancaster, WI. Disease severity was rated as $1=$ no to very slight discoloration of roots and hypocotyl; $2=$ slight necrosis of roots and hypocotyl; $3=$ necrosis of roots and hypocotyl; 4 = extensive necrosis of roots, hypocotyl, and cotyledons; and $5=$ dead. Data are means of three replications.

Table 3. Disease severity indices ${ }^{\mathrm{a}}$ for five alfalfa populations inoculated with 14 Aphanomyces euteiches isolates from Iowa alfalfa fields

\begin{tabular}{|c|c|c|c|c|c|c|c|}
\hline \multirow[b]{2}{*}{ Isolate } & \multirow[b]{2}{*}{ Origin } & \multicolumn{5}{|c|}{ Alfalfa population or cultivar } & \multirow[b]{2}{*}{ Mean } \\
\hline & & Agate & Quantum & Paramount & WAPH-1 & WAPH-2 & \\
\hline 111 & Montgomery Co., IA & 4.2 & 4.0 & 4.3 & 3.7 & 2.6 & 3.8 \\
\hline 71 & Ringgold Co., IA & 4.5 & 4.2 & 4.3 & 4.4 & 3.0 & 4.1 \\
\hline 86 & Clarke Co., IA & 4.5 & 4.3 & 4.3 & 4.1 & 2.7 & 4.0 \\
\hline 112 & Montgomery Co., IA & 4.5 & 4.3 & 4.0 & 3.6 & 2.3 & 3.7 \\
\hline 75 & Allamakee Co., IA & 4.3 & 4.3 & 4.3 & 4.0 & 2.7 & 3.9 \\
\hline 100 & Linn Co., IA & 4.5 & 4.0 & 4.4 & 4.3 & 3.2 & 4.1 \\
\hline 98 & Cedar Co., IA & 4.3 & 3.8 & 4.1 & 4.1 & 2.5 & 3.8 \\
\hline 90 & Iowa Co., IA & 4.5 & 4.2 & 4.3 & 4.0 & 3.0 & 4.0 \\
\hline 89 & Benton Co., IA & 4.9 & 3.9 & 4.8 & 4.2 & 2.4 & 4.0 \\
\hline 116 & Dubuque Co., IA & 4.2 & 3.5 & 3.6 & 3.0 & 1.8 & 3.2 \\
\hline 62 & Monroe Co., IA & 3.8 & 3.2 & 3.8 & 3.4 & 1.8 & 3.2 \\
\hline 109 & Pottawattamie Co., IA & 4.6 & 3.7 & 3.9 & 4.2 & 2.3 & 3.7 \\
\hline 73 & Ringgold Co., IA & 3.9 & 3.6 & 3.8 & 3.1 & 2.5 & 3.4 \\
\hline \multirow[t]{3}{*}{72} & Ringgold Co., IA & 4.6 & 3.6 & 4.1 & 4.1 & 2.2 & 3.7 \\
\hline & Uninoculated & 1.1 & 1.2 & 1.1 & 1.2 & 1.2 & 1.2 \\
\hline & Mean & 4.2 & 3.7 & 3.9 & 3.7 & 2.4 & 3.6 \\
\hline
\end{tabular}

${ }^{\text {a }}$ Disease severity was rated as $1=$ no to very slight discoloration of roots and hypocotyl; $2=$ slight necrosis of roots and hypocotyl; $3=$ necrosis of roots and hypocotyl; $4=$ extensive necrosis of roots, hypocotyl, and cotyledons; and $5=$ dead. Data are means of three experiments. Disease severity differed significantly among isolates and alfalfa populations $(P<0.0001)$, and their interaction was significant $(P=0.001)$. 
and the group resistant to both pathogens yielded significantly higher than the group susceptible to $P$. medicaginis. McNay is considered the most disease-prone of the locations (because of soil type), and it displayed the most consistent differences in yield between resistant and susceptible cultivars, with mean yields about $17 \%$ higher for the resistant versus susceptible cultivar groups. Yields among the three groups of resistant cultivars (resistant to $A$. euteiches race 1 , resistant to $P$. medicaginis, or resistant to both) were almost identical within location at Ames, Nashua, and Castana. At Castana, which is considered the least disease-prone site, yields were

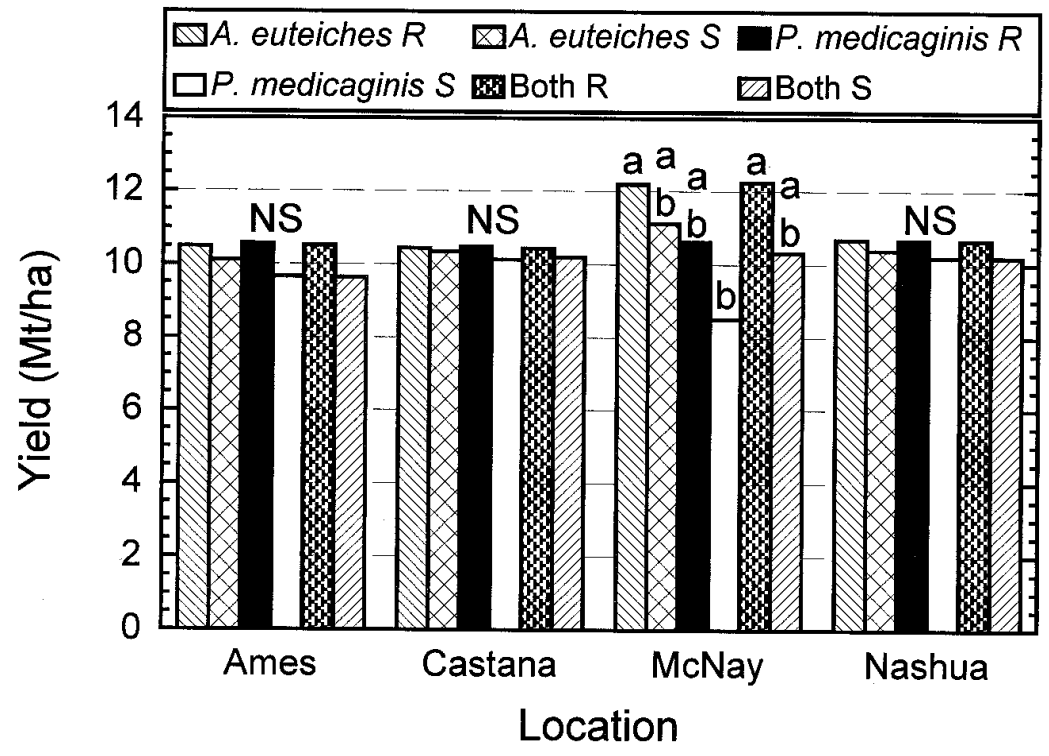

Fig. 2. Mean annual yield of alfalfa cultivars harvested at Iowa State University research farms from 1992 through 1997. Data are combined for different aged stands and harvest years within locations (26 total location-years). Cultivars are grouped into six categories according to their resistance to Aphanomyces euteiches or Phytophthora medicaginis: A. euteiches $\mathrm{R}=$ resistant to A. euteiches (regardless of $P$. medicaginis resistance); A. euteiches $\mathrm{S}=$ susceptible to A. euteiches (regardless of $P$. medicaginis resistance); $P$. medicaginis $\mathrm{R}=$ resistant to $P$. medicaginis (regardless of $A$. euteiches resistance); P. medicaginis $\mathrm{S}=$ susceptible to $P$. medicaginis (regardless of A. euteiches resistance); Both $\mathrm{R}=$ resistant to both $A$. euteiches and $P$. medicaginis; Both $\mathrm{S}=$ susceptible to both $A$. euteiches and P. medicaginis. A. euteiches was detected at Ames, McNay, and Nashua; P. medicaginis was detected only at McNay. Within a location, bars with the same letter are not significantly different (at $P=0.05)$ according to least-squares means comparisons. NS $=$ no significant difference (at $P=0.05$ ).

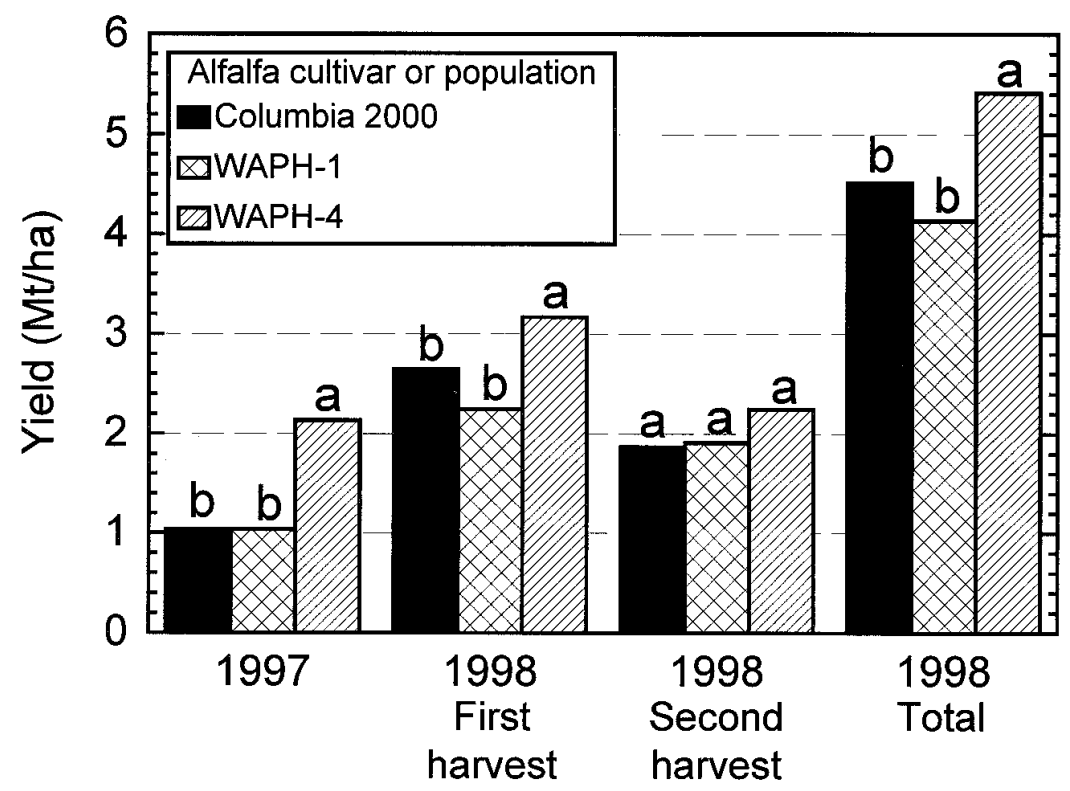

Fig. 3. Yields of three alfalfa populations planted at Lancaster, WI, in 1997 and harvested in 1997 and 1998. Bars within a group and with the same letter are not significantly different (least significant difference at $\alpha=0.05$ ). numerically very similar among all the cultivar groups. Forage yields differed significantly among harvest years at each location $(P<0.001)$. There were no significant interactions involving cultivar resistance.

These results differ from those obtained in a previous study performed in Wisconsin (31), in which resistance to these two pathogens was associated with more distinct plant health benefits. Stand counts (plants per plot), plant vigor (on a 1 to 5 scale), and root health (1 to 3 scale) were significantly better for the resistant cultivars in that study. Yields of resistant cultivars also were superior to susceptible cultivars, but yield data were presented only for a single year (1993, a year with excessive rainfall). Rainfall varied among years and locations of this study; only one stand was harvested in 1993 and other years were not as wet as 1993. In this study, yields differed significantly among harvest years, but relative yield performance of the cultivar groups (resistant versus susceptible) did not differ significantly among years. The benefits of resistance to $\mathrm{A}$. $\mathrm{eu}$ teiches and $P$. medicaginis were more evident in the Wisconsin study (31) than in the current study. This result may have been due to more disease-conducive weather during the Wisconsin study, or a difference in A. euteiches race structure between the two states. In a similar study conducted in Kentucky over 4 years and four locations, cultivars selected for resistance to A. euteiches yielded significantly greater as a group than varieties lacking resistance. However, there was no correlation between yield and percentage of plants with resistance among the cultivars (28). The authors concluded that planting cultivars resistant to A. euteiches contributed to improvement of alfalfa germ plasm for poorly drained soils, but this factor alone was not sufficient to predict high yield. In both these published studies, the resistant cultivars were selected for resistance to race 1 of A. euteiches.

The growth chamber results suggest that A. euteiches race 2 is common in Iowa and Wisconsin, and this may have limited the benefits of the A. euteiches race 1 resistant cultivars planted in the field test sites. Unfortunately, A. euteiches isolates from the Iowa locations did not produce zoospores in the laboratory, and therefore we did not confirm the presence of race 2 at these field-test locations. The A. euteiches population in the Wisconsin location was well characterized, with $36 \%$ of the isolates assigned to race 2. Currently, $A$. euteiches- and $P$. medicaginis-resistant cultivars are routinely recommended for planting in both states; in Iowa, resistance to these two pathogens is strongly recommended in the south-central part of the state. This recommendation exists primarily because of stand establishment problems that occur with susceptible cultivars. 
We could not detect stand establishment problems in this study because the data were collected from existing stands. The yields for cultivars resistant to these two pathogens were significantly higher than for the susceptible cultivars at McNay, in south-central Iowa. The lack of statistical differences in yields at the other locations does not make a convincing case for the yield benefits of resistance statewide, but may reflect the prevalence of race 2 in Iowa. Clearly, there was no "yield penalty" associated with the resistant cultivars, even in years and locations (e.g., Castana) where root rot diseases were unlikely to affect yield. It is possible that incorporation of resistance to race 2 of $A$. euteiches will improve the performance of A. euteichesresistant cultivars in Iowa.

In Wisconsin, yield of WAPH-4 was significantly higher than those of Columbia 2000 and WAPH-1 for 1997, for the first harvest in 1998, and for the total yield in 1998 (Fig. 3). Dry soil conditions during the second growth period in 1998 likely contributed to a lack of yield difference among alfalfa populations for the second harvest. The superior performance of WAPH-4 at the race 2-infested Wisconsin site indicates that race 2 lowers the agronomic performance of race 1-resistant alfalfa cultivars. Data from the Wisconsin location provide further evidence that race 1-resistant cultivars may have limited value in Iowa, not because A. euteiches is not capable of reducing forage yield, but rather because race 1-resistant cultivars do not have adequate resistance against race 2 . Although less common in Wisconsin than in Iowa, race 2 of $A$. euteiches must be considered as an explanation when race 1resistant and-susceptible cultivars do not differ in agronomic performance. Preliminary data indicate that the frequency of race 2 is increasing in Wisconsin (C. R. Grau, unpublished).

\section{ACKNOWLEDGMENTS}

We are grateful for the assistance of Marco Buske, James Fawcett, Brian Lang, Joseph Narigon, Carroll Olsen, and Allen Seim (Iowa State University Extension), who collected samples from which A. euteiches isolates were isolated. Jessica Brummer and Sharie Fitzpatrick (Forage Genetics, Inc.) generously provided technical advice. We thank Kara Scott and Kevin Silveira for technical assistance. This research was partially supported by ABI Alfalfa, Ames, IA; Cal/West Seeds, Woodland, CA; Pioneer HiBred International, Johnston, IA; and WL Research, Evansville, WI.

\section{LITERATURE CITED}

1. Beute, M. K., and Lockwood, J. L. 1967. Pathogenic variability in Aphanomyces euteiches. Phytopathology 57:57-60.

2. Brummer, E. C., and Crim, L. 1997. The 1997 Iowa crop performance test - alfalfa. Ia. State Univ. Ext. Publ. AG-84.

3. Delwiche, P. A., Grau, C. R., Holub, E. B., and Perry, J. B. 1987. Characterization of Aphanomyces euteiches isolates recovered from alfalfa in Wisconsin. Plant Dis. 71:155-161.

4. Frosheiser, F. I., and Barnes, D. K. 1973. Field and greenhouse selections for Phytophthora root rot resistance in alfalfa. Crop Sci. 13:735-738.

5. Grau, C. R. 1990. Aphanomyces root rot. Pages 10-11 in: Compendium of Alfalfa Diseases. American Phytopathological Society, St. Paul, MN.

6. Grau, C. R. 1992. Registration of WAPH-1 germplasm with resistance to Aphanomyces root rot. Crop Sci. 32:287-288.

7. Grau, C. R. 1994. Development of alfalfa germplasm WAPH-2 resistant to Aphanomyces root rot. NCR-138 Report for Wisconsin, 1994.

8. Grau, C.R. 1994. Variability in virulence within populations of Aphanomyces euteiches. NCR-138 Report for Wisconsin, 1994.

9. Grau, C. R., Muehlchen, A. M., Tofte, J. E., and Smith, R. R. 1991. Variability in virulence of Aphanomyces euteiches. Plant Dis. 75: 1153-1156.

10. Gray, F. A., Bohl, W. H., and Wofford, D. S. 1988. Relationships of increasing levels of resistance of Phytophthora root rot in alfalfa to stand longevity and yield. Plant Dis. 72:10641067.

11. Hoagland, D. R., and Arnon, D. I. 1950. The water culture method for growing plants without soil. Calif. Agric. Exp. Stn. Circ. 347.

12. Holub, E. B., and Grau, C. R. 1990. Ability of Aphanomyces euteiches to cause disease of seedling alfalfa compared with Phytophthora megasperma f. sp. medicaginis. Phytopathology 80:331-335.

13. Holub, E. B., and Grau, C. R. 1990. Specificity of resistance to Aphanomyces euteiches in seedling alfalfa. Plant Dis. 74:164-168.

14. Holub, E. B., Grau, C. R., and Parke, J. L. 1991. Evaluation of the forma specialis concept in Aphanomyces euteiches. Mycol. Res. 95:147-157.

15. Hudelson, B. D., and Grau, C. R. 1998. Development of a standardized test for evaluating alfalfa for resistance to Aphanomyces euteiches Race 2. Page 29 in: Proc. N. Am. Alfalfa Improve. Conf., 36th.

16. Jones, F. R., and Drechsler, C. 1925. Root rot of peas in the United States caused by Aphanomyces euteiches. J. Agric. Res. 30:293-325.
17. Lindford, M. B. 1927. Additional hosts of Aphanomyces euteiches, the pea root rot fungus. Phytopathology 17:133-134.

18. Littell, R. C., Freund, R. J., and Spector, P. C. 1991. SAS System for Linear Models, 3rd ed. SAS Institute, Cary, NC.

19. Lueschen, W. E., Barnes, D. K., Rabas, D. L., Frosheiser, F. I., and Smith, D. M. 1976. Field performance of alfalfa cultivars resistant and susceptible to Phytophthora root rot. Agron. J. 68:281-285.

20. Malvick, D. K., Grau, C. R., and Percich, J. A. 1998. Characterization of Aphanomyces euteiches strains based on pathogenicity tests and random amplified polymorphic DNA analysis. Mycol. Res. 102:465-475.

21. Malvick, D. K., and Percich, J. A. 1998 Variation in pathogenicity and genotype among single-zoospore strains of Aphanomyces euteiches. Phytopathology 88:52-57.

22. Manning, M. A., and Menzies, S. A. 1984 Pathogenic variability in isolates of Aphanomyces euteiches from New Zealand soils. N.Z. J. Agric. Res. 27:569-574.

23. McKeen, W. E., and Traquair, J. A. 1980. Aphanomyces sp., an alfalfa pathogen in Ontario. Can J. Plant Pathol. 2:42-44.

24. Munkvold, G. P., and Carlton, W. M. 1995. Prevalence and distribution of Aphanomyces euteiches and Phytophthora medicaginis in Iowa alfalfa fields. Plant Dis. 79:1251-1253.

25. Parke, J. L., and Grau, C. R. 1992. Aphanomyces. Pages 27-30 in: Methods for Research on Soilborne Phytopathogenic Fungi. L. L. Singleton, H. D. Mihail, and C. M. Rush, eds. American Phytopathological Society, St. Paul, $\mathrm{MN}$.

26. Pfender, W. F., Delwiche, P. A., Grau, C. R., and Hagedorn, D. J. 1984. A medium to enhance recovery of Aphanomyces from infected plant tissue. Plant Dis. 68:845-847.

27. Schmitthenner, A. F. 1964. Prevalence and virulence of Phytophthora, Aphanomyces, Pythium, Rhizoctonia, and Fusarium isolated from diseased alfalfa seedlings. Phytopathology 54:1012-1018.

28. Vincelli, P., Lauriault, L. M., and Henning, J. C. 1995. Yields of alfalfa varieties selected for Aphanomyces resistance in Kentucky. Agron. J. 87:748-752.

29. Vincelli, P., Nesmith, W. C., and Eshenaur, B. C. 1994. Incidence of Aphanomyces euteiches and Phytophthora medicaginis in Kentucky alfalfa fields. Plant Dis. 78:645-647.

30. Vincelli, P. C. 1992. Potential for seedling disease of alfalfa caused by Aphanomyces euteiches in a Kentucky soil. Plant Dis. 76:622-626.

31. Wiersma, D. W., Grau, C. R., and Undersander, D. J. 1995. Alfalfa cultivar performance with differing levels of resistance to Phytophthora and Aphanomyces root rots. J. Prod. Agric. 8(2):259-264.

32. Wilkinson, H. T., and Millar, R. L. 1981. Phytophthora root rot of alfalfa in central New York. Plant Dis. 65:127-129. 
ERRATUM / Volume 85, Number 3, 2001

In the article "Virulence of Aphanomyces euteiches Isolates from Iowa and Wisconsin and Benefits of Resistance to A. euteiches in Alfalfa Cultivars" by G. P. Munkvold, W. M. Carlton, E. C. Brummer, J. R. Meyer, D. J. Undersander, and C. R. Grau, pages 328 to 333, for Figures 2 and 3, the y-axis labels should be: Yield (t/ha).

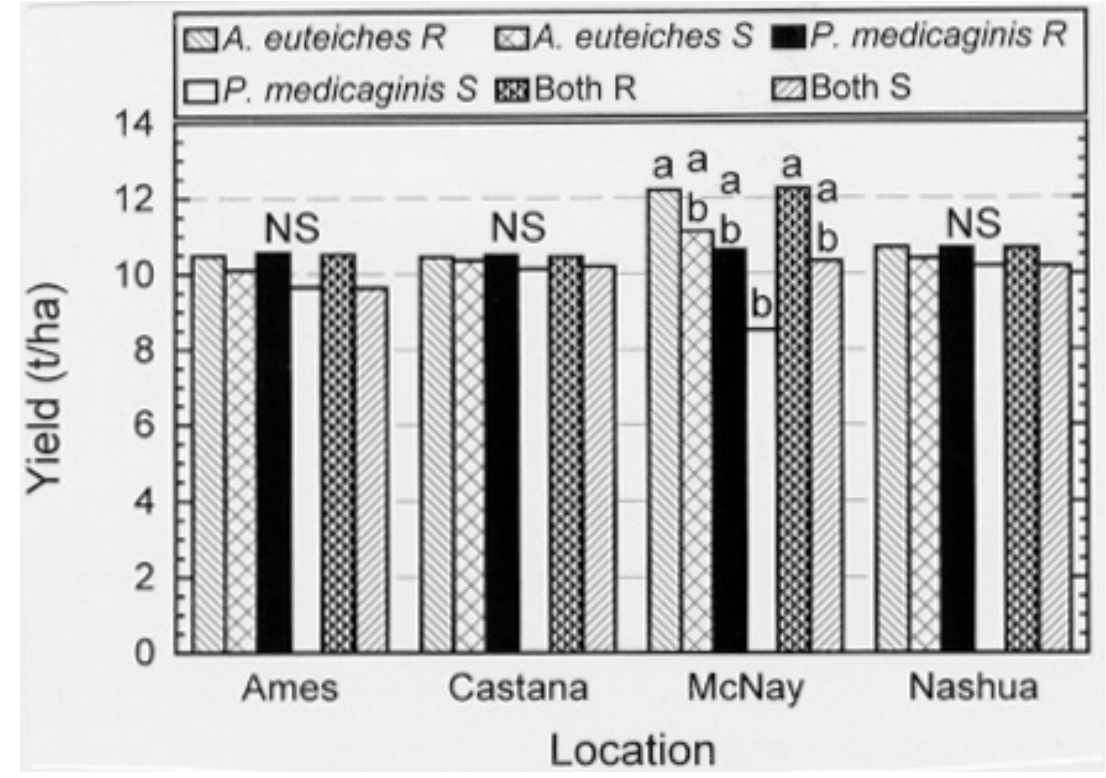

Fig. 2. Mean annual yield of alfalfa cultivars harvested at Iowa State University research farms from 1992 through 1997. Data are combined for different aged stands and harvest years within locations (26 total location-years). Cultivars are grouped into six categories according to their resistance to Aphanomyces euteiches or Phytophthora medicaginis: A. euteiches $\mathrm{R}=$ resistant to A. euteiches (regardless of $P$. medicaginis resistance); A. euteiches $\mathrm{S}=$ susceptible to A. euteiches (regardless of $P$. medicaginis resistance); $P$. medicaginis $\mathrm{R}=$ resistant to $P$. medicaginis (regardless of $A$. euteiches resistance); P. medicaginis $\mathrm{S}=$ susceptible to $P$. medicaginis (regardless of A. euteiches resistance); Both $\mathrm{R}=$ resistant to both $A$. euteiches and $P$. medicaginis; Both $\mathrm{S}=$ susceptible to both $A$. euteiches and P. medicaginis. A. euteiches was detected at Ames, McNay, and Nashua; P. medicaginis was detected only at McNay. Within a location, bars with the same letter are not significantly different (at $P=0.05$ ) according to least-squares means comparisons. NS $=$ no significant difference (at $P=0.05$ ).

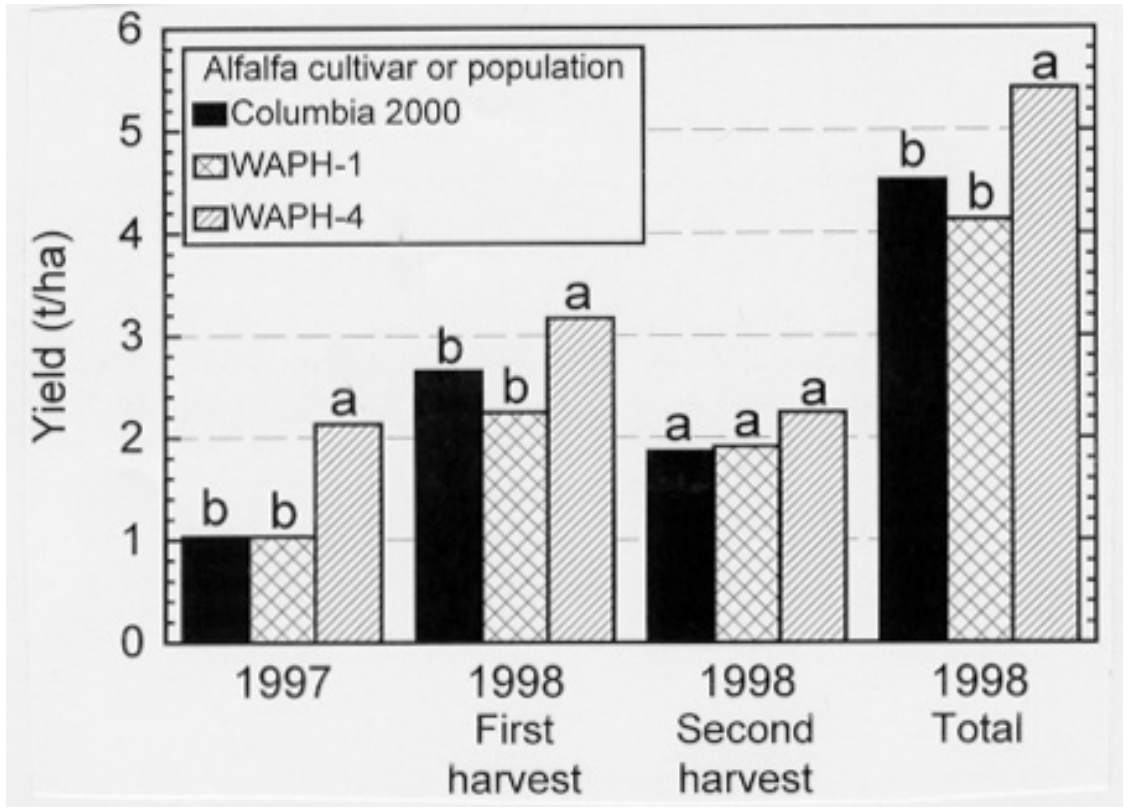

Fig. 3. Yields of three alfalfa populations planted at Lancaster, WI, in 1997 and harvested in 1997 and 1998. Bars within a group and with the same letter are not significantly different (least significant difference at $\alpha=0.05$ ). 